\title{
THE IMPORTANCE OF HUMAN CAPITAL IN THE STRATEGIC DEVELOPMENT OF AN ORGANIZATION
}

\author{
Adriana Grigorescu \\ National University of Political Studies and Public Administration, Bucharest; Valahia \\ University from Targoviste, Romania \\ adriana.grigorescu@administratiepublica.ro \\ Anca Chiper (Neculau) \\ Valahia University from Targoviste, Romania; Castilla-La Mancha University from Spain \\ anca.chiper@yahoo.com
}

\begin{abstract}
In this new world where the level of information has reached overwhelming thanks to new technologies, the human capital embodied in a stock value, skill and knowledge, becomes the main factor of production in the new economy. In this paper I have tried to emphasize that, this relatively new concept such as human capital has become the main motor of organizational development, representing one of the most important advantages of firms to work properly in their environments. The economic growth is conditioned by human capital development; current trends are changing and organizations change their outward form of thought and action and they enhance their human capital (this intangible asset too little highlighted and measured) from the desire of being more flexible and easily assimilated by the market in the future. For modern companies, human capital has become a "golden coin" with 2 sides called: 1) capability (the ability to provide solutions to customers through knowledge, skills, knowhow, and talent); 2) attitude (the ability to profitably use these values of the organization). In conclusion, human capital is measured using IQ and the productivity of modern economies depend largely on investment in knowledge and skills, although statistics in Romania do not include costs and expenses of human capital.
\end{abstract}

\section{Keywords}

new economy; human capital; solutions; know-how; investment in knowledge and skills; "gold coin" of the organization

\section{JEL Classification}

M10

\section{Human capital}

World technology should be constantly on the move, improving itself, and it basically stands for an indispensable tool for productivity as well as for the market, yet one should consider the fact that any innovation success depends greatly on the flexibility and vision of the people making part of any relevant organization.

Nowadays, information and technology run fast and they come "in handy" for any organization, while the main competitive advantage differentiating one given company from another is rendered by the personnel within such organization, as well as by the latter's ability to achieve fast adjustment to new changes. This may be achieved by one's ability to constantly learn, to be open to new things, by designing 
one's own education and experience, all corroborated within one given system of skills and competences.

In one such organization, competences arise out of the relevant business strategy and the same should be observed, measured, aligned to company's strategies and generating constant benefits. All this stands for quite a challenge for both the human resources departments and for the managers in general, since the latter shall be responsible for understanding and meeting customers' wishes and needs, so as to bring a relevant and truly tangible contribution to the business they run. Enhancing and maintaining competitive benefits within one given company may be carried out by human capital management.

Human capital stands for the knowledge that each and every single individual possesses.

Human capital is defined as the creative hand within one given organization and it stands for the most significant and most vital resource for one to develop the said business activity, the productivity in terms of goods and services for the purpose of meeting clients' needs and to sell the same on the relevant market in view of getting profit.

Material means turn into one finished product following their going through the production process, yet it is human capital that stands for that particular force building this entire system by means of talent and ability.

Human capital springs out of companies' need to rely upon one high tech instrument, which shall provide for support in production, since any last generation machine is unable to manage by itself, yet it requires supervisors, as well as workers. Any organization is that dynamic and economic entity, where the following factors shall be relevant:

- Economic capital

- Human capital

- Company management.

A company object is strictly related to such human capital; the economic capital is related to investors and management relates to managers and administrators.

The human capital (humans-talent.blogspot.ro) has the following characteristics:

- knowledge

- skills

- virtues

All these variables turn the employee into the main pawn within any given organization, as well as into the main driving element in terms of creativity, production, vision, all of the aforementioned making such employee an indispensable factor at any company level. Upon the more and more acute perception of the globalization concept, organizations require the maintenance of one up - to - date trained and qualified personnel, holding decisional power and who shall bring all processes having been started to a good end, within the shortest possible period of time.

The staff within one given organization is very important since it adds value to the latter and the creativity around them is part of one company's long term strategy. Managers should invest in the personnel, by protecting, evaluating, constantly developing, awarding and remunerating the latter.

Competences within one given organization spring out of the relevant strategy; the same should be observable, measureable, aligned to the day - to - day strategy of any given company and generating competitive and sustainable benefits so as not to be able to be "copied" by any competitors (www.geopolis.com). 
Human talent in any given organization is genuine, this being far more difficult to be replayed by competitors, and thus investing in human capital stands for one of the most significant pillars of any company. The criterion relating to the hierarchies based upon which success relied in the past, has gradually changed within the recent years, and at present the primary relevance in any company is granted to the competences such individual holds and at the same time to the latter's attitude towards his ability to acquire new skills that may be of use for the organization.

The yield in terms of human capital investments stands for one final indicator in terms of the measuring process, which involves the collection of data for the display of outcomes, as per various levels of interest:

- customer satisfaction within the project, as run by the organization at that specific time

- learning for the purpose of acquiring new knowledge and skills

- applying the aforementioned on the job

- the impact of the above described results upon the relevant business.

Human capital has created a new metaphor at the global level: the employee may act as one new investor in any given organization. People stand for the driving element of change since they hold the know - how resource, thus organizations should bear in mind the constant changes undergone by the business environment and to align their internal productivity towards innovation, analysis and new approaches.

The human capital concept has set its mark in the specialized literature as of 1961, the year of the release in the American Economic Review, of the article written by Theodore W. Schultz, namely "Investment in Human Capital". Laureate of the Noble Prize for Economy, exponent of the New School in Chicago - whose theoretical lead and slogan was:" Man - the most precious richness of any country ". Knowledge and skills make up the relevant capital and this capital stands for the outcome of one deliberate and willing investment.

The concept of such human capital corresponds to any individual's skills and knowledge enabling the later to achieve change in action and to reach economic growth (Coleman J.,1988).

Human capital may be developed by formal training and education, focusing on updating and renewing any individual's abilities. One should make a distinction between the various distinct types of human capital, as follows:

Company specific human capital consists of those particular abilities and knowledge that are relevant within one given company. For instance, some researchers have investigated the impact held by company know - how within the founding team on the increase ratio of the companies that were at the beginning of their business activity.

At the company level, human capital is regarded as one component of the intellectual capital (Edvinsson, 1997) together with the relevant structural capital. Human capital is defined as the value of company employees' knowledge, skills and experience, and structural capital is defined as the "body and supporting infrastructure of human capital, namely all those things that make up the human capital support in any given company and which are left aside when the employees leave the company at the end of the day" (Edvinsson, 1997).

McElroy Mark (2001) stretches out and expands the relevant scope of analysis, adding to the human and structural capital, the relevant registered capital within the composition of the intellectual capital. In reference to its structural dimension, he defines the capital as being "the general model of connections between actors".

The industrial branch specific capital consists in that knowledge deriving out of the specific experience in any relevant industry. Various researchers have investigated the 
impact held by the experience in a specific industrial branch upon economic growth and economic performance, at both micro and macro - economic level (Siegel, MacMillan, 1993, Kenney, von Burg, 1990).

Individual specific human capital refers to that knowledge applicable to a wide range of companies and industries; it includes managerial and entrepreneurial experience (Pennings, Lee \& van Witteloostujin, 1998), the level of academic education and professional training (Hinz \&Junghauer-Gans, 1999), such individual's age and family incomes (Kilkenny, Nalbarte \&Besser, 1999).

Within the relevant most recent economic literature, one speaks of the neoclassical theory of human capital, as well as of such human capital management and strategy. The latter stands for one form of active management - a plan for the insurance, management and motivation of the relevant labor force in view of business performance optimization.

Human capital, as one central production factor in any given economic theory stands for the stock of knowledge and qualifications that are useful and valuable, as integrated into the relevant labor force, resulting out of one education and professional training process. It relates to any individual's ability to mobilize other production factors, to specifically combine the same and to predetermine so as to reach the expected and wished for outcome. It is upon this human capital that our richness depends, as well as the richness of our future generations, too. Therefore, the establishment of such human capital should enjoy the highest priority, all the more that without the support of an adequate knowledge and human experience, the other production factors shall not be able to produce but very little, if anything at all.

The benefit following such human capital investment does not resume itself to the net amount of incomes, as achieved during a life time, out of the sale of qualified labor force unlike the unqualified one, but it also focuses on the subjective feeling of intellectual wellbeing, of trust, as well as of social acknowledgment. According to estimates, between 50 and $90 \%$ of the overall capital stock in the US takes the form of human capital.

Human capital has various distinct meanings in terms of the various groups of interests:

\section{- Employers}

In the business world, human capital stands for the economic value of one set of skills that employees hold; traditionally, it has been perceived as an education and experience function (the last one standing for both the training the employees have received, and the hands - on learning, as gathered by means of experience). Within the recent years, one has also added health to the list (physical, cognitive and mental capacity);

\section{- Society}

There is also the long term vision of human capital. This includes indicators resulting out of decisional practices and policies which shall have an impact on future generations and which shall shape the form of tomorrow's labor force. Quite often, this long term vision does not fit the political cycles and investment type scopes, yet the lack of such long term vision may trigger the constant loss of one country's population potential, as well as dropping of productivity level, just as things stand as far as our country is concerned.

\section{- Individual}

The individual shows interested in activating on a labor market which should enable him to achieve professional expression, the accurate acknowledgment and rewarding of his own value, which should provide for his mobility, a satisfactory health and wellbeing status, as well as the appurtenance to a good reputation human capital (in terms of education, productivity). Romania belongs to the Upper-mid income group of 
countries, which means that it pays better here than in Albania and Serbia, yet the payment is worse than in Hungary, Bulgaria, Macedonia, which countries belong to the same aforementioned group (Mocanu, 2014).

Competitiveness stands for the outcome of talent and the abilities resulting out of such human capital. Any organization, regardless of the business activity the latter carries out, if it wishes to maintain one adequate long term competitiveness level, should use formal decisional and analysis procedures that should be embedded within the context of strategic planning.

The role played by this process is that of coordinating and systematizing all efforts of the various number of units, as conceived in view of one's maximizing the overall organization efficiency.

Internal competitiveness refers to the organization ability to reach maximum performance in terms of available resources, such as personnel, capital, materials, ideas, etc., as well as the relevant transformation processes: the company shall compete against itself, while stating its constant self-overdoing efforts (http://www.mundosigloxxi.ciecas.ipn.mx).

External competitiveness is oriented towards the development of organization successes within the context of the current market: industry dynamism and economic stability.

Once it has reached the relevant external competitiveness level, a company should maintain the same in the future, by generating ideas and products and it should also look for new opportunities on the market.

Nowadays, in this age of changes, companies wishing to increase their productivity, efficiency ratios, as well as the quality services, tend to use as a central basis for the human element, the development of teams, so as to achieve competitiveness and to adequately reply to the demand for high quality products and services at all levels, as concerned.

Corporate management quality has just as much relevance for any given organization, as technology and products innovation have. Upon consideration of this aforementioned concept, we cannot help wondering if it might be reasonable for one to conduct a comprehensive, fruitful and development related research in terms of companies' management, for the purpose of creating new instruments for the organization to impose its competitiveness on the market. In the $3^{\text {rd }}$ millennium, companies should turn their attention towards human capital management, by management processes which shall trigger a positive influence on the employees and which shall consolidate the required teams, so as to enhance productivity, in order for one to consider two main factors:

The Environment stands for a challenge for any given company:

- market evolution and expansion

- $\quad$ products diversification

- new technologies coming up on the market

The innovating social-economic management, as elaborated and experienced by Savall H. (Jean Moulin University) stands for one management method closely integrating the human dimension of one given company and the latter's economic performances.

His global level management methods rely on the human development of the company as the main factor for short, average and long term efficiency.

Companies and enterprises efficiency and efficacy depend a great deal on their own ability to articulate traditional management methods with a human and social vision in terms of the latter's operation and they closely integrate the human dimension of the company and the latter's economic performances (Savall, 2006). 
Human capital may conduct either manual or intellectual works, and the latter may apply to various activity fields, such as industry, agriculture or services.

The labor force, or the working ability that such human capital possesses is represented by the set of physical and intellectual abilities that the individual holds and applies within the production for the purpose of meeting the relevant needs.

One study conducted in 1999 by PricewaterhouseCoopers in terms of the best human management practices, has reached the conclusion that the most significant skills one individual should possess in order to survive and develop and grow within the business world in the following years, are represented by:

- $\quad$ leadership,

- $\quad$ adjustability to changes,

- $\quad$ people management,

- teamwork.

Thus, the role played by human capital within one given organization is vital, and without the latter's capitalization, the company's wish to align to market objectives and to enhance competitiveness would lack any meaning whatsoever.

\section{References}

Edvinddon L., Malone M. (1997), Intellectual Capital, Harper Business.

Feraru, A., (2011), Intellectual capital and knowledges-premises of he organizational development Proceeding Progress, Innovation, Democracy Horizon 2025, Tg. Jiu, pp. 631-635.

Feraru, A., Ciucescu N. (2011), Knowledge and the intellectual capital in modern organizations, Annals of the Oradea University. Fascicle of Management and Technological Engineering, ISSN 1583-0691, ISBN 978-606-10-0128-6 pp. 5106-5111.

Mendez Juan Carlos, (2006), La importancia del capital humano en las organizaciones, www.gestiopolis.com, 18.02.2006.

Mocanu R., http://itol.ro/directory/2014/02/valoarea-capitalului-uman-romanesc, Bucuresti, 14 Feb 2014.

Ruiz Victor R.L. and Domingo N. Pena, (2002), El capitalintelectual:valoracion y medicion / Pearson Education.

Savall Henry, (2006), Theorie socio-economique des organisations:impacts sur quelques concepts dominants dans les theories et pratiques manageriales, Coloquio y Seminario Doctoral Internacional, Lyon, France, 24-25 de avril.

Valadez Guillermo Velazquez, Las organizaciones y el capital humano, http://www.mundosigloxxi.ciecas.ipn.mx/.

W.Schultz T. (1961), Investment in human capital, American Science Review.

W.McElroy M., (2001), Social Inovation Capital, www.macroinovation.com.

humans-talent.blogspot.ro/ Jonathan Zegarro, Talento Humano, La importancia del capital humano en las organizaciones.

www.stiucum.com/management, Capitalul uman - forta fundamental a dezvoltarii, accessed on 03.03.2016.

www.geopolis.com/.

http://www.mundosigloxxi.ciecas.ipn.mx/. 
Grigorescu, Chiper (Neculau) 